\section{Phosphorus Concentration Affects New Guinea Impatiens and Vinca in Recirculating Subirrigation}

\author{
Carrie L. Whitcher, ${ }^{1}$ Matthew W. Kent, ${ }^{2}$ and David Wm. Reed ${ }^{3}$ \\ Department of Horticultural Sciences, Texas A\&MUniversity, College Station, \\ TX 77843-2133
}

Additional index words. ebb-and-flow, ebb-and-flood, plant nutrition, phosphate, electrical conductivity

\begin{abstract}
The objective of this study was to quantify the optimum rates of water-soluble phosphorus (P) under constant nitrogen and potassium on the growth of new guinea impatiens (Impatiens hawkeri Bull.) 'Paradise Violet' and vinca Catharanthus roseus 'Pacifica Red' in soilless media in a recirculating subirrigation system. The experiment was designed so that only phosphate varied between treatments while all other nutrients remained constant. The ammoniacal $N$ to nitrate $N$ ratio was varied to counter balance increases in phosphate. Sodium was used as a counter ion to phosphate at higher concentrations of phosphate; sodium proved to be toxic at concentrations above $6 \mathrm{mM}$. In the new guinea impatiens experiment, there was a small increase in $K$ due to the use of dibasic K phosphate to buffer $\mathrm{pH}$. All growth parameters measured (height, leaf number, flower number, and shoot fresh and dry weight) showed significant differences with increasing $P$ rate. Depending on the growth parameter measured, quadratic-linear models revealed an optimum $P$ rate of 0.1 to $0.96 \mathrm{~mm}$ for new guinea impatiens 'Paradise Violet' and 0.45 to $1.25 \mathrm{~mm}$ P for vinca 'Pacifica Red'. For dry shoot weight, a common measure of optimum plant growth, the optimum $P$ rate was $0.75 \mathrm{~mm} P$ for new guinea impatiens 'Paradise Violet' and $0.67 \mathrm{~mm} P$ for vinca 'Pacifica Red'. For flower number, a common measure of floral quality, the optimal $P$ rate was $0.96 \mathrm{~mm} P$ for new guinea impatiens 'Paradise Violet' and $1.25 \mathrm{mM} P$ for vinca 'Pacifica Red'. Electrical conductivity (EC) of the growing media increased significantly with increasing rate of $P$. At all rates, EC was significantly greater in the top layer than in the bottom and middle layers. The $\mathrm{pH}$ of the growing medium did not vary in relation to $P$ concentration.
\end{abstract}

Pollution of surface water, particularly from phosphate accumulation in lakes, rivers, and coastal drainages has generated national attention and valid concerns for a dwindling fresh water supply. Eutrophication has been linked to phosphate water contamination, a key factor leading to fertility restrictions in several states (Carpenter et al., 1998; Gburek and Sharpley, 1998).

Phosphorus leaching from soilless media in commercial container production is a problem due to three factors. First, water-soluble fertilizers, continuous-liquid feed fertilizers, and controlled-release fertilizers often are used in excess due to their success in growth enhancement with intensively managed crops

Received for publication 30 June 2005. Accepted for publication 27 July 2005 We thank Paul Ecke Ranch, Encinitas, Calif. and Speedling Inc, Blairsville, Ga. for providing plant material, Sun Gro, Terrell, Texas for growing medium, and grant support from the Texas Ornamental Enhancement Program. We also thank George Fernandez, Dept. Applied Economics and Statistics, University of Nevada-Reno, and Nancy Carter and Neil Schwertman, Dept. of Mathematics and Statistics, California State University, Chico, for assistance on the statistical analysis. Use of trade names does not imply endorsement of products named or criticism of similar products not mentioned.

${ }^{1}$ Graduate student project.

${ }^{2}$ Senior research associate.

${ }^{3}$ Professor, to who reprint requests should be addressed; e-mail dwreed@tamu.edu. overabundance of fertilizer adds excessive $P$ in leachate from top-watered irrigation systems (Haver and Schuch, 1996). Third, soilless media have less ability to retain $\mathrm{P}$ than mineral soils (Yeager and Wright, 1982), causing more $\mathrm{P}$ losses into the environment.

Although superphosphate routinely is placed in soilless media as an insurance against Pdeficiency, tissue Plevels of 'Mrs. G.G. Gerbing' azaleas (Rhododendron L.) were shown not to differ with or without superphosphate amendment in combination with or without dolomitic limestone (Yeager and Ingram, 1986). As of yet there are no commercial solid medium production systems in which low sustained in the growing medium solution (Williams and Nelson, 1996) either with insoluble or water-soluble P forms. An equilibrium soil solution concentration as low as $0.00646 \mathrm{mM}$ phosphate $\mathrm{P}$ has been shown to be adequate for optimal growth of several crop plant species (Beckwith, 1965), including field-grown chrysanthemum (Nishimoto, et al., 1975). For other crops, including poinsettia, Baas (1995) found that $0.24 \mathrm{~mm} \mathrm{P}$ did not inhibit growth and plant development in ebb-and-flow irrigation. Phosphorus concentrations of $0.003 \mathrm{~mm}$ have been shown to be sufficient for maximum growth of different species in solution culture (First and Edwards, 1987; Lynch etal., 1991). In Lupinus mutabilis Sweet 'Potosi', Passarinho
(Yelanich and Biernbaum, 1993). Second, this phosphate concentrations are achieved and et al. (2000) demonstrated highest growth and photosynthesis rates at the $0.5 \mathrm{mMP}$ level in aerated nutrient solution irrigation. In hydroponics with chrysanthemum, $0.1 \mathrm{~mm}$ was shown to maintain high root respiration without affecting shoot biomass (Hansen and Lynch, 1998). A common commercial recommendation for top-watering is to use $\mathrm{P}$ (expressed as $\mathrm{P}_{2} \mathrm{O}_{5}$ ) at $50 \%$ the rate of $\mathrm{N}$ application, which for a general constant feed program would be (in $\mathrm{mg} \cdot \mathrm{L}^{-1}$ ) $200 \mathrm{~N}-100 \mathrm{P}_{2} \mathrm{O}_{5}-200 \mathrm{~K}_{2} \mathrm{O}$ (Nelson, 1996) or (in mM) $14.3 \mathrm{~N}-1.4 \mathrm{P}-5.1 \mathrm{~K}$.

The use of zero-leach irrigation systems provides a method of retaining lower levels of water-soluble $\mathrm{N}-\mathrm{P}-\mathrm{K}$ in solution without compromising quality of the crop or releasing nutrients in irrigation runoff (Reed, 1996; James and van Iersel, 2001a) and allows sustained $\mathrm{P}$ retention in soilless media (Williams and Nelson, 1996). Previous experiments have shown lower than normally recommended rates for nitrogen (Kent and Reed, 1996) and potassium (Haley and Reed, 2004) to be optimum in recirculating subirrigation compared to recommended constant feed rates in top-watering systems (Nelson, 1996). Begonias grown with 1.6 or $3.2 \mathrm{~mm}$ P had $38 \%$ more flowers, and had greater dry weight, height, and width than plants grown with $0 \mathrm{mM} P$ (James and van Iersel, 2001b). Lettuce (Lactuca sativa) transplants, irrigated by ebb-and-flow flotation irrigation, required at least $0.48 \mathrm{~mm} P$ for sufficient root growth and rapid field establishment (Soundy et al., 2001).

Due to the wide range of data in the literature on the effect of rate of water-soluble $\mathrm{P}$ on horticultural crops, the objective of this study was to determine the optimum rate of water-soluble $P$ in a recirculating subirrigation system, using new guinea impatiens and vinca as model plants. New guinea impatiens is used as a model plant that is somewhat salt sensitive and performs better under milder temperatures, and vinca is used as a model plant that is somewhat more salinity tolerant and can be adequately grown under high summer temperatures in the south.

\section{Materials and Methods}

New guinea impatiens rate experiment. New guinea impatiens 'Paradise Violet' rooted cuttings (Paul Ecke Ranch, Encinitas, Calif.) were transplanted into $11-\mathrm{cm}$-wide $\times 9.5-\mathrm{cm}$ tall $(460-\mathrm{mL})$ plastic containers on 19 Nov. 2002. Soilless growing medium used was a 2 peat: 1 perlite: 1 vermiculite (by volume) mix, unadjusted for $\mathrm{pH}$ (beginning $\mathrm{pH}=5.75$ ), with no preplant macronutrient charge, and amended with $1.1 \mathrm{~kg} \cdot \mathrm{m}^{-3}$ Micromax trace element mix (The Scotts Co., Marysville, Ohio.). Newly transplanted cuttings were top-watered three times with reverse osmosis-purified water (RO) to settle the medium. After the initial RO irrigation, pots were placed into subirrigation trays $(52 \times 52$-cm subirrigation trays, SpencerLemaire, Edmonton, AB) on two greenhouse benches with ten plants per tray. Each subirrigation tray had its own individual reservoir of fertilizer solution which was supplied by a submersible pump (Mini-Jet MN 606, Aquarium 
Table 1. Composition of nutrient solution for the new guinea impatiens 'Paradise Violet' and vinca 'Pacifica Red' experiments in recirculating subirrigation.

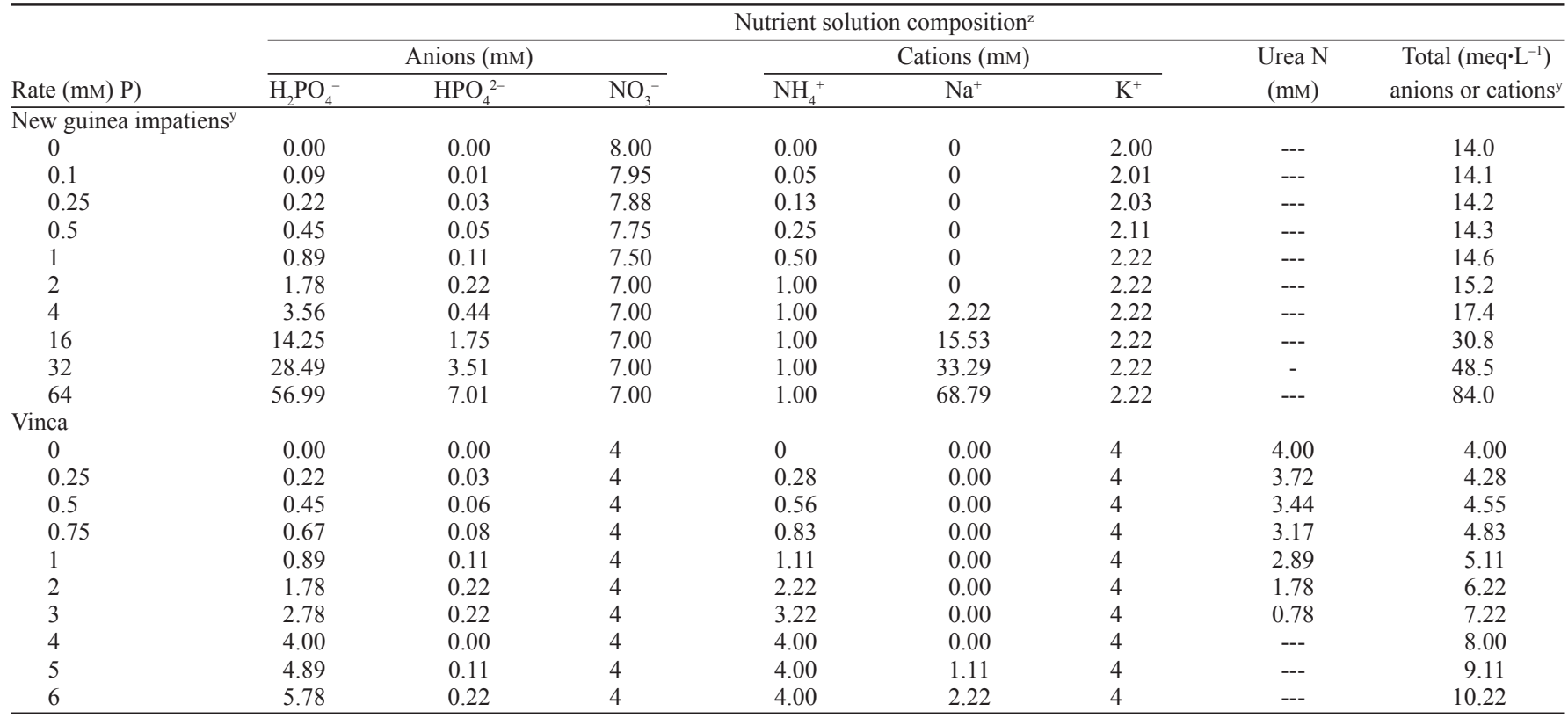

${ }^{2}$ The following chemicals were used to prepare the nutrient solutions: $\mathrm{K}_{2} \mathrm{HPO}_{4}, \mathrm{KH}_{2} \mathrm{PO}_{4},\left(\mathrm{NH}_{4}\right)_{2} \mathrm{HPO}_{4}, \mathrm{NH}_{4} \mathrm{H}_{2} \mathrm{PO}_{4}, \mathrm{NaH}_{2} \mathrm{PO}_{4}, \mathrm{Na}_{2} \mathrm{HPO}_{4}, \mathrm{NH}_{2} \mathrm{CONH}_{2}, \mathrm{KNO}_{3}$, $\mathrm{NH}_{4} \mathrm{NO}_{3}, \mathrm{NaNO}_{3}, \mathrm{Ca}\left(\mathrm{NO}_{3}\right)_{2}, \mathrm{MgSO}_{4}$, and $\mathrm{CaSO}_{4}$.

Number represents sum of anions or cations; sum of anions equals sum of cations

'In addition, all solutions contained $2 \mathrm{mM} \mathrm{Mg}^{+2}, 4 \mathrm{~mm} \mathrm{Ca}^{+2}$, and $3 \mathrm{mM} \mathrm{SO}_{4}^{-2}$

Systems, Mentor, Ohio). Submersible pumps were manually turned on to flood the trays, which took about five minutes. Trays were held flooded 1 to $2 \mathrm{~cm}$ deep for about $10 \mathrm{~min}$, allowing each pot's media surface to become saturated, and then were completely drained, which took about $5 \mathrm{~min}$. Subirrigation started on 23 Nov. 2002 and was terminated on 22 Feb. 2003 (day 91). The experiment was conducted in a glasshouse with average daily noontime and midnight temperatures, relative humidity, and light intensity of $23.1^{\circ} \mathrm{C}, 20.5^{\circ} \mathrm{C}, 69.4 \%$, and $201 \mu \mathrm{mol} \cdot \mathrm{m}^{-2} \cdot \mathrm{s}^{-1}$ photosynthetic photon flux (PPF) (HOBO H8 sensor, Quantum Light Logger model 3600, Spectrum Technol., Inc, Plainfield, Ill.), respectively.

Experimental design was a single factorial randomized block design of 10 rates: 0 , $0.1,0.25,0.5,1,2,4,16,32$, and $64 \mathrm{~mm}$ P. For each treatment concentration, there were five individual plant replications located in an individual tray; and bench location effect was blocked for on two adjacent benches. Statistical analysis revealed nonsignificant block effects, and pooled data is presented. Since there were only five plants remaining in the each tray at final harvest contributing to the final data, there was no subsampling. Phosphorus was supplied by $\mathrm{K}_{2} \mathrm{HPO}_{4}, \mathrm{KH}_{2} \mathrm{PO}_{4}, \mathrm{NaH}_{2} \mathrm{PO}_{4}$, and $\mathrm{Na}_{2} \mathrm{HPO}_{4}$. In rate studies of single nutrient ions, one has the complication of concurrent increases in the counter ion. The nutrient solutions in these experiments were designed to allow increasing phosphate concentration while holding the concentration of all other nutrients constant, except for a small increase in $\mathrm{K}$ concentration $(11 \%)$ in the 0 to $2 \mathrm{~mm} P$ treatments. The small increase in $\mathrm{K}$ was due to the use of a combination of $\mathrm{K}_{2} \mathrm{HPO}_{4}$ and $\mathrm{KH}_{2} \mathrm{PO}_{4}$ in order to buffer the solution to $\mathrm{pH}$ 6.3. Total $\mathrm{N}$ was maintained constant at $8 \mathrm{~mm}$ by making adjustments in the nitrogen form used $\left(\mathrm{NH}_{4}^{+}\right.$and $\left.\mathrm{NO}_{3}^{-}\right)$. Sodium was used as the counter cation in the $4 \mathrm{~mm}$ and above $\mathrm{P}$ treatments. Table 1 gives the nutrient solutions used to achieve increasing phosphate concentration, while holding all other nutrient concentrations constant. Since the growing medium contained no additives, $\mathrm{Ca}\left(\mathrm{NO}_{3}\right)_{2}$, $\mathrm{MgSO}_{4}$, and $\mathrm{CaSO}_{4}$ were added to yield $\mathrm{Mg}$ at $2 \mathrm{~mm}, \mathrm{Ca}$ at $4 \mathrm{~mm}$, and sulfate at $3 \mathrm{~mm}$. For all treatments up to $2 \mathrm{~mm} \mathrm{P}, \mathrm{P}$ and $\mathrm{K}$ were supplied with $\mathrm{K}_{2} \mathrm{HPO}_{4}$ and $\mathrm{KH}_{2} \mathrm{PO}_{4}$. For the $4 \mathrm{~mm}$ $\mathrm{P}$ and above treatments, the additional $\mathrm{P}$ was supplied as $\mathrm{NaH}_{2} \mathrm{PO}_{4}$ and $\mathrm{Na}_{2} \mathrm{HPO}_{4}$.

Plant height (soil surface to top of tallest leaf), leaf number and flower number (opened flowers) were measured weekly. At final harvest (day 91), plant tops were cut off at the medium surface, and leaf area (model AM82 leaf area meter; Delta-T Devices Ltd., Cambridge, U.K.) and fresh weight were measured. Plant tops were dried at $40^{\circ} \mathrm{C}$ for $72 \mathrm{~h}$, and then weighed for dry weight. The growing medium of each pot was cut into three equal-sized horizontal layers (top, middle and bottom), air dried, and subsamples were removed from each layer to determine electrical conductivity (EC) and $\mathrm{pH}$ by the 1:2 dilution method (Warncke and Krauskopf, 1983). EC was measured using a conductivity-TDS meter (model 44600; Hach Co., Loveland, Colo.) and pH was measured using a pH meter (model 701A; Orion Research, Cambridge, Mass.).

Vinca rate experiment. The new guinea impatiens experiment was repeated with vinca. However, this experiment was designed to better define the rate in the optimum range. This experiment used more rates at the lower $P$ concentrations, the medium used for this experiment was a commercially available product that was adjusted with lime to stabilize $\mathrm{pH}, \mathrm{K}$ was constant in all treatments, and the use of $\mathrm{Na}$ as a counter cation was minimized.

Seedlings of vinca 'Pacifica Red' (Speed- ling Inc, Blairsville, Ga.) were transplanted as in the new guinea impatiens Rate Expt. with the exception of the medium used. A commercial peat-perlite medium, Sunshine \#2 (Sun Gro Horticulture, Bellevue, Wash.) was used for this experiment. The medium contained lime to adjust $\mathrm{pH}$, contained no preplant macronutrient charge, and was amended with $1.1 \mathrm{~kg} \cdot \mathrm{m}^{-3}$ Micromax trace element mix (The Scotts Co., Marysville, Ohio). The experimental design was a randomized complete block design with three blocks of ten concentrations of water-soluble phosphorus, and 10 replications per treatment. Five plants were harvested per treatment at mid-experiment and at termination. Statistical analysis revealed nonsignificant block effects, hence pooled data is presented. The $\mathrm{P}$ rates were 0 , $0.25,0.5,0.75,1,2,3,4,5$, and $6 \mathrm{mM} P$ from $\mathrm{KH}_{2} \mathrm{PO}_{4}, \mathrm{~K}_{2} \mathrm{HPO}_{4},\left(\mathrm{NH}_{4}\right)_{2} \mathrm{HPO}_{4}, \mathrm{NH}_{4} \mathrm{H}_{2} \mathrm{PO}_{4}$, $\mathrm{NaH}_{2} \mathrm{PO}_{4}$, and $\mathrm{Na}_{2} \mathrm{HPO}_{4}$. Potassium was raised to a constant $4 \mathrm{~mm}$, which limited the use of $\mathrm{Na}$ as a counter ion to 5 and $6 \mathrm{mM}$ P. The nitrate $\mathrm{N}$ :ammoniacal $\mathrm{N}$ ratio was constant at $4: 4 \mathrm{~mm}$. Urea was used as the ammoniacal source where lesser amounts of ammonium phosphate were used at the lower P concentrations. Since the growing medium contained lime, $\mathrm{Ca}$ and $\mathrm{Mg}$ were not added to the fertilizer solution as in the new guinea impatiens experiment. The experiment started on 9 May 2003 and was terminated on 20 June 2003 (day 42). The same plant growth and growing medium parameters measured in the new guinea impatiens rate experiment were determined, except for the separation of growing medium layers. The results of the first experiment showed no statistical difference between bottom and middle medium layers. Thus, the growing medium was separated into the upper third and bottom two-thirds for $\mathrm{pH}$ and EC measurements. Average daily noontime and midnight greenhouse 


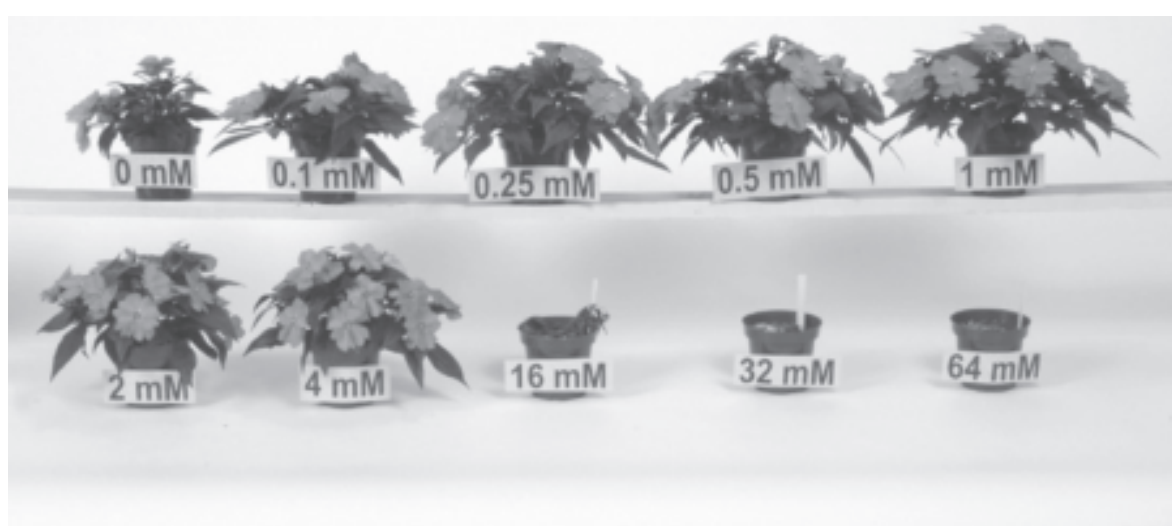

Fig. 1. New guinea impatiens 'Paradise Violet' grown at rates of $0,0.1,0.25,0.5,1,2,4,16,32$, and 64 $\mathrm{mM} P$ in a recirculating subirrigation system (day 91 , final harvest).

temperatures, relative humidity, and light intensity were $30.3{ }^{\circ} \mathrm{C}, 23.8^{\circ} \mathrm{C}, 63.7 \% \mathrm{RH}$, and $360 \mu \mathrm{mol} \cdot \mathrm{m}^{-2} \cdot \mathrm{s}^{-1} \mathrm{PPF}(\mathrm{HOBO} \mathrm{H} 8$ sensor, Quantum Light Logger model 3600, Spectrum Technol., Inc.), respectively.

Statistical analysis was analysis of variance (ANOVA) by SAS and JMP IN v. 4.0, and optimum $\mathrm{P}$ rates were determined by fitting a quadratic-linear segmented model or quadratic-plateau model using Proc Nlin

(SAS Institute Inc., Cary, N.C.). Optimum P is defined as the point where the quadratic and linear models join.

\section{Results and Discussion}

New guinea impatiens rate experiment. Control plants were stunted, with purple leaves, fewer flowers, necrotic spotting, and reduced height typical of P deficiency (Fig. 1). There

Table 2. The effect of rate of water-soluble phosphate on growth response of new guinea impatiens 'Paradise Violet' grown in a recirculating subirrigation system at final harvest (day 91).

\begin{tabular}{|c|c|c|c|c|c|}
\hline & & & & $\begin{array}{l}\text { Shoot } \\
\text { fresh }\end{array}$ & $\begin{array}{c}\text { Shoot } \\
\text { dry }\end{array}$ \\
\hline $\begin{array}{l}\text { Rate } \\
(\mathrm{mm} \mathrm{P})\end{array}$ & $\begin{array}{l}\mathrm{Ht} \\
(\mathrm{cm})\end{array}$ & $\begin{array}{c}\text { Leaves } \\
\text { (no.) }\end{array}$ & $\begin{array}{c}\text { Flowers } \\
\text { (no.) }\end{array}$ & $\begin{array}{l}\text { wt } \\
(\mathrm{g})\end{array}$ & $\begin{array}{l}\text { wt } \\
(\mathrm{g})\end{array}$ \\
\hline 0 & $9.0 \mathrm{~d}^{\mathrm{z}}$ & $58.2 \mathrm{f}$ & $4.4 \mathrm{~d}$ & $23.1 \mathrm{f}$ & $2.3 \mathrm{f}$ \\
\hline 0.1 & $10.8 \mathrm{c}$ & $125.4 \mathrm{e}$ & $11.8 \mathrm{bc}$ & $70.6 \mathrm{de}$ & $6.0 \mathrm{e}$ \\
\hline 0.25 & $13.3 \mathrm{a}$ & $180.6 \mathrm{~cd}$ & $14.8 \mathrm{ab}$ & $89.7 \mathrm{c}$ & 7.5 cde \\
\hline 0.5 & $13.0 \mathrm{ab}$ & $224.0 \mathrm{a}$ & $11.8 \mathrm{bc}$ & $90.7 \mathrm{bc}$ & $7.6 \mathrm{bcd}$ \\
\hline 1.0 & $13.0 \mathrm{ab}$ & $199.0 \mathrm{bc}$ & $18.2 \mathrm{a}$ & $109.4 \mathrm{a}$ & $8.8 \mathrm{a}$ \\
\hline 2.0 & $13.0 \mathrm{ab}$ & $204.4 \mathrm{ab}$ & $13.0 \mathrm{~b}$ & $101.9 \mathrm{ab}$ & $8.3 \mathrm{ab}$ \\
\hline 4.0 & $12.2 \mathrm{~b}$ & $161.2 \mathrm{~d}$ & $13.4 \mathrm{~b}$ & $77.0 \mathrm{~d}$ & $6.8 \mathrm{de}$ \\
\hline \multicolumn{6}{|l|}{ ANOVA significance } \\
\hline Rate & $* * *$ & $* * *$ & $* * *$ & $* * *$ & $* * *$ \\
\hline Optimum rate & 0.10 & 0.49 & 0.96 & 0.87 & 0.75 \\
\hline Model & $* * * *$ & $* * * *$ & $* * * *$ & $* * * *$ & $* * * *$ \\
\hline
\end{tabular}

${ }^{2}$ Mean separation within columns by LSD, $P \leq 0.05(\mathrm{n}=5)$.

${ }^{y}$ Determined using a quadratic-linear segmented model using SAS Proc Nlin.

${ }^{* * * * * * * *}$ Significant at $P \leq 0.001$ or 0.0001 , respectively.

Table 3. Growing medium electrical conductivity (EC) of top, middle and bottom layers of new guinea impatiens 'Paradise Violet' grown with varying rates of water-soluble phosphate in recirculating subirrigation at final harvest (day 91). ${ }^{\mathrm{z}}$

\begin{tabular}{lccc}
\hline & & \multicolumn{2}{c}{$\begin{array}{c}\mathrm{EC}^{\mathrm{z}} \\
\left(\mathrm{dS} \cdot \mathrm{m}^{-1}\right)\end{array}$} \\
\cline { 2 - 4 } Rate & \multicolumn{3}{c}{ Layer } \\
\cline { 2 - 4 }$(\mathrm{mM} \mathrm{P})$ & Bottom & Middle & Top \\
\hline 0 & 0.50 & $0.52 \mathrm{~g}$ & 2.86 \\
0.1 & 0.75 & $0.95 \mathrm{ab}$ & 3.77 \\
0.25 & 0.77 & $0.80 \mathrm{bcde}$ & 2.44 \\
0.5 & 0.52 & $0.56 \mathrm{fg}$ & 3.12 \\
1 & 0.56 & $0.63 \mathrm{defg}$ & 2.75 \\
2 & 0.59 & $0.58 \mathrm{efg}$ & 2.99 \\
4 & 0.77 & $0.83 \mathrm{abcd}$ & 3.80 \\
ANOVA significance & & & \\
$\quad$ Rate & $\mathrm{NS}$ & $* * *$ & $\mathrm{NS}$ \\
$\quad$ Layer & $* * *$ & $* * *$ & $\mathrm{NS}$ \\
$\quad$ Rate $\times$ layer & $\mathrm{NS}$ & $* * *$ & \\
\hline
\end{tabular}

'Initial growing media EC was $1.24 \mathrm{dS} \cdot \mathrm{m}^{-1}$.

${ }^{y}$ Mean separation within columns by LSD, $P \leq 0.05(\mathrm{n}=5)$.

NS,****Nonsignificant or significant at $P \leq 0.001$. was a significant effect of $P$ rate on all growth parameters measured, and as P rate increased, growth parameters increased, then decreased (Table 2). In the three highest treatments (16, 32 , and $64 \mathrm{~mm}$ ), Na was used as the primary counter cation. Salt injury was extensive in these three highest treatments, causing plant death prior to final harvest. One is unable to determine if this is a $\mathrm{Na}$ or phosphate toxicity, but one could speculate that it is primarily due to sodium. The data from the $16 \mathrm{~mm}$ and above treatments were not used in the statistical analysis.

Quadratic-linear segmented model analysis revealed an optimum P rate of 0.1 to $0.96 \mathrm{mM}$, depending on the growth parameter measured (Tables 2, 3, and 4). For dry shoot weight, a common measure of optimum vegetative plant growth, the optimal $\mathrm{P}$ rate was $0.75 \mathrm{~mm}$. For flower number, a common measure of floral capacity, the optimum $\mathrm{P}$ rate was $0.96 \mathrm{~mm}$. These optimum $\mathrm{P}$ rates are appreciably less than the optimum rate of $8 \mathrm{mM} \mathrm{N}$ (Kent and Reed, 1996) and 2 mm K (Haley and Reed, 2004) determined for new guinea impatiens grown in recirculating subirrigation.

Excessive salts did not accumulate in the bottom two-thirds layer (Table 5), as indicated by the EC being below the recommended maximum EC of 1.2 to $1.5 \mathrm{dS} \cdot \mathrm{m}^{-1}$ for established plants (Lang, 1996; Warncke and Krauskopf, 1983). Excessive salts accumulated in the upper layer in all treatments, as indicated by EC values that were slightly higher than the recommended maximum. This has been a common observation in previous experiments (Argo and Biernbaum, 1995; Kent and Reed, 1996; Haley and Reed, 2004).

The final $\mathrm{pH}$ of the growing medium averaged $4.1 \pm 0.1$ ( \pm standard error), and did not vary in relation to increasing $P$ rate. This is significantly lower than the recommended $\mathrm{pH}$ of 5.5 to 6.5 (Lang, 1996) for greenhouse crops. In an attempt to control the known ionic content of the system, lime was not added to the medium at the beginning of the experiment. Soluble $\mathrm{Ca}$ and $\mathrm{Mg}$ were supplied in the treatment solutions. It was hoped that the high nitrate $\mathrm{N}$ level of the fertilizer solutions (Table 1) would help to maintain a higher growing medium $\mathrm{pH}$, but evidently it could not overcome the natural acidity of the peat moss lowering $\mathrm{pH}$ over time. Despite this, the lower $\mathrm{pH}$ values did not appear to affect plant growth or quality in the best treatments (Fig. 1).

Vinca rate experiment. As with new guinea impatiens 'Paradise Violet', the control plants were stunted with minimal growth (Figs. 2 and 3).

Quadratic-linear segmented and quadratic-plateau model analysis revealed an optimum P rate of 0.45 to $1.25 \mathrm{~mm}$, depending on the growth parameter measured (Table 4). For dry shoot weight, a common measure of optimum plant growth, the optimum $\mathrm{P}$ rate was $0.67 \mathrm{~mm}$. This is slightly lower than the optimum rates found for new guinea impatiens 'Paradise Violet'. For flower number, a common measure of floral capacity, the optimum $P$ rate was $1.25 \mathrm{~mm}$.

As with the new guinea impatiens experi- 
Table 4. The effect of rate of water-soluble phosphate on growth response of vinca 'Pacifica Red' grown in a recirculating subirrigation system at final harvest (day 42).

\begin{tabular}{|c|c|c|c|c|c|}
\hline & & & & $\begin{array}{l}\text { Shoot } \\
\text { fresh }\end{array}$ & $\begin{array}{c}\text { Shoot } \\
\text { dry }\end{array}$ \\
\hline $\begin{array}{l}\text { Rate } \\
(\mathrm{mM} \mathrm{P})\end{array}$ & $\begin{array}{c}\mathrm{Ht} \\
(\mathrm{cm})\end{array}$ & $\begin{array}{c}\text { Leaves } \\
\text { (no.) }\end{array}$ & $\begin{array}{c}\text { Flowers } \\
\text { (no.) }\end{array}$ & $\begin{array}{l}\text { wt } \\
(\mathrm{g})\end{array}$ & $\begin{array}{l}\text { wt } \\
(\mathrm{g})\end{array}$ \\
\hline 0 & $5.9 \mathrm{f}^{z}$ & $16.4 \mathrm{e}$ & $0.5 \mathrm{f}$ & $1.19 \mathrm{e}$ & $0.24 \mathrm{f}$ \\
\hline 0.25 & $16.8 \mathrm{e}$ & $151.5 \mathrm{~d}$ & $7.0 \mathrm{e}$ & $32.09 \mathrm{~d}$ & $4.42 \mathrm{e}$ \\
\hline 0.5 & $20.8 \mathrm{ab}$ & $176.8 \mathrm{c}$ & $13.8 \mathrm{~d}$ & $42.94 \mathrm{~b}$ & $6.01 \mathrm{~b}$ \\
\hline 0.75 & $20.2 \mathrm{bc}$ & $205.5 \mathrm{a}$ & $14.1 \mathrm{~cd}$ & $45.98 \mathrm{a}$ & $6.45 \mathrm{a}$ \\
\hline 1.0 & $21.4 \mathrm{a}$ & $182.9 \mathrm{bc}$ & $17.2 \mathrm{~b}$ & $47.89 \mathrm{a}$ & $6.42 \mathrm{a}$ \\
\hline 2.0 & $19.7 \mathrm{bc}$ & $196.9 \mathrm{a}$ & $20.7 \mathrm{a}$ & $46.87 \mathrm{a}$ & $6.36 \mathrm{a}$ \\
\hline 3.0 & $21.6 \mathrm{a}$ & $193.4 \mathrm{ab}$ & $21.1 \mathrm{a}$ & $46.10 \mathrm{a}$ & $6.19 \mathrm{ab}$ \\
\hline 4.0 & $19.1 \mathrm{~cd}$ & $183.0 \mathrm{bc}$ & $16.8 \mathrm{bc}$ & $39.52 \mathrm{c}$ & $5.67 \mathrm{c}$ \\
\hline 5.0 & $20.0 \mathrm{bcd}$ & $176.9 \mathrm{c}$ & $16.8 \mathrm{bc}$ & $40.33 \mathrm{c}$ & $5.32 \mathrm{~d}$ \\
\hline 6.0 & $19.0 \mathrm{~d}$ & $163.6 \mathrm{~d}$ & $16.8 \mathrm{bc}$ & $39.33 \mathrm{c}$ & $5.10 \mathrm{~d}$ \\
\hline \multicolumn{6}{|c|}{ ANOVA significance } \\
\hline Rate & $* * *$ & $* * *$ & $* * *$ & $* * *$ & $* * *$ \\
\hline Optimum rate & $0.49^{y}$ & $0.45^{y}$ & $1.25^{\mathrm{y}}$ & $0.73^{x}$ & $0.67^{x}$ \\
\hline Model & $* * * *$ & $* * * *$ & $* * * *$ & $* * * *$ & $* * * *$ \\
\hline
\end{tabular}

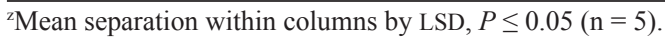

yDetermined with a quadratic-plateau model using SAS Proc Nlin.

${ }^{x}$ Determined with a quadratic-linear segmented model using SAS Proc Nlin.

${ }^{* * * * * * * *}$ Significant at $P \leq 0.001$ or 0.0001 , respectively.

Table 5. Growing medium electrical conductivity (EC) of top one-third and bottom two-thirds layers of vinca 'Pacifica Red' grown with varying rates of water-soluble phosphate in recirculating subirrigation at final harvest (day 42).

\begin{tabular}{lcc}
\hline & & $\mathrm{EC}^{\mathrm{z}}\left(\mathrm{dS} \cdot \mathrm{m}^{-1}\right)$ \\
\cline { 2 - 3 } $\begin{array}{l}\text { Rate } \\
(\mathrm{mM} \mathrm{P})\end{array}$ & $\begin{array}{c}\text { Bottom } \\
2 / 3\end{array}$ & $\begin{array}{c}\text { Top } \\
1 / 3\end{array}$ \\
\hline 0 & $0.64 \mathrm{a}^{\mathrm{y}}$ & $2.05 \mathrm{a}$ \\
0.25 & $0.29 \mathrm{c}$ & $1.48 \mathrm{e}$ \\
0.5 & $0.25 \mathrm{~cd}$ & $1.61 \mathrm{~cd}$ \\
0.75 & $0.24 \mathrm{~d}$ & $1.48 \mathrm{e}$ \\
1 & $0.24 \mathrm{~d}$ & $1.71 \mathrm{~b}$ \\
2 & $0.26 \mathrm{~cd}$ & $1.71 \mathrm{~b}$ \\
3 & $0.25 \mathrm{~cd}$ & $1.63 \mathrm{c}$ \\
4 & $0.35 \mathrm{~b}$ & $1.55 \mathrm{~d}$ \\
5 & $0.39 \mathrm{~b}$ & $1.78 \mathrm{~b}$ \\
6 & $0.35 \mathrm{~b}$ & $1.61 \mathrm{~cd}$ \\
ANOVA significance & & $* * *$ \\
$\quad$ Rate & $* * *$ & $\mathrm{NS}$ \\
$\quad$ Layer & $* * *$ & $\mathrm{NS}$ \\
$\quad$ Rate $\times$ layer & $* * *$ & \\
\hline
\end{tabular}

${ }^{2}$ Initial growing medium EC was $0.79 \mathrm{dS} \cdot \mathrm{m}^{-1}$.

y Mean separation within columns by LSD, $P \leq 0.05(\mathrm{n}=5)$.

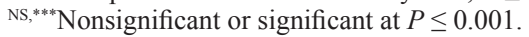

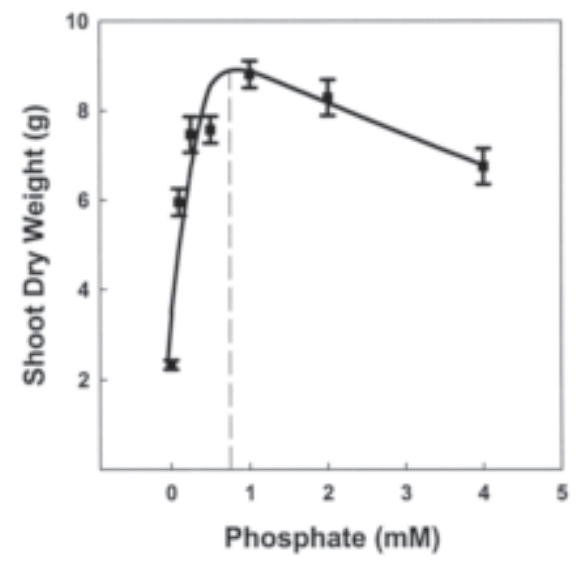

Fig. 2. Final harvest dry shoot weight (g) of new guinea impatiens 'Paradise Violet' grown at rates of 0 to $4 \mathrm{~mm} P$ in a recirculating subirrigation system (day 91, final harvest). Dashed line indicates optimum mм $P$ as defined by where the linear joins the quadratic line of the segmented quadratic-linear model. Bars indicate \pm standard error of the mean. low rates of $\mathrm{P}$ (Beckwith, 1964; Hansen and Lynch, 1998; Nishimoto et al., 1975). Taking into account these results and those of Kent and Reed (1996) for N, and Haley and Reed (2004) for K, the optimum rate for growth of new guinea impatiens in subirrigation is $8 \mathrm{~N}-0.75 \mathrm{P}-2 \mathrm{~K}(\mathrm{mM})$, which on a molar basis is a ratio of about 11:1:3. This corresponds to $112 \mathrm{~N}-53 \mathrm{P}_{2} \mathrm{O}_{5}-94 \mathrm{~K}_{2} \mathrm{O}\left(\mathrm{mg} \cdot \mathrm{L}^{-1}\right)$, or about a 2:1:2 fertilizer ratio, which agrees with common commercially recommended fertilizer ratios for general greenhouse crops (Nelson, 1996). These rates for subirrigation are about half the common commercially recommended rates of (in $\mathrm{mg} \cdot \mathrm{L}^{-1}$ ) $200 \mathrm{~N}-100 \mathrm{P}_{2} \mathrm{O}_{5}-200 \mathrm{~K}_{2} \mathrm{O}$ for top-watering (Nelson, 1996), which emphasizes the lesser amount of N-P-K needed for adequate plant growth in subirrigation.

\section{Literature Cited}

Argo, W.R. and J.A. Biernbaum. 1995. The effect of irrigation method, water-soluble fertilization, preplant nutrient charge, and surface evaporation on early vegetative and root growth of poinsettia. J. Amer. Soc. Hort. Sci. 120:163-169.

Baas, R. 1995. Growth regulation of bedding plants and poinsettia using low phosphorus fertilization and ebb-and flow irrigation. Acta Hort. 378:129-137.

Beckwith, R.S. 1965. Sorbed phosphate at standard supernatant concentration as an estimate of the phosphate needs of soils. Austral. J. Expt. Agr. Anim. Husb. 5:52-58.

Carpenter, S.R., N.F Caraco, D.L. Correll, R.W. Howarth, A.N. Sharpley, and V.H. Smith. 1998. Nonpoint pollution of surface waters with phosphorus and nitrogen. Ecol. Appl. 8:559-568.

First, A.J. and D.G. Edwards. 1987. External phosphorus requirements of five tropical grain legumes grown in flowing-solution culture. Plant Soil 99:75-84.

Gburek, W.J. and A.N. Sharpley. 1998. Hydrologic controls on phosphorus loss from upland agricultural watersheds. J. Environ. Qual. 27:267-277

Haley, T.B. and D.W. Reed. 2004. Optimum potassium concentrations in recirculating subirrigation for selected greenhouse crops. HortScience 39:1441-1444.

Hansen, C.W. and J. Lynch. 1998. Response to phosphorus availability during vegetative and reproductive growth of chrysanthemum: II. Biomass and phosphorus dymanics. J. Amer. Soc. Hort. Sci. 123:223-229.

Haver, D.L. and U.K. Schuch. 1996. Production and postproduction performance of two new guinea impatiens cultivars grown with controlled-release fertilizer and no leaching. J. Amer. Soc. Hort. Sci. 121:820-825.

James, E.C. and M.W. van Iersel. 2001a. Fertilizer concentration affects growth and flowering of subirrigated petunias and begonias. HortScience 36:40-44.

James, E.C. and M.W. van Iersel. 2001b. Ebb and flow production of petunias and begonias as affected by fertilizers with different phosphorus content. HortScience 36:282-285.

Kent, M.W. and D.W. Reed. 1996. Nitrogen nutrition of new guinea impatiens 'Barbados' and Spathiphyllum 'Petite' in a subirrigation system. J. Amer. Soc. Hort. Sci. 121:816-819.

Lang, H.J. 1996. Growing media testing and interpretation, p. 123-140. In: D.W. Reed(ed.). Water, media and nutrition for greenhouse crops. Ball Publ., Batavia, Ill.

Lynch, J., A. Läuchli, and E. Epstein. 1991. Crop 


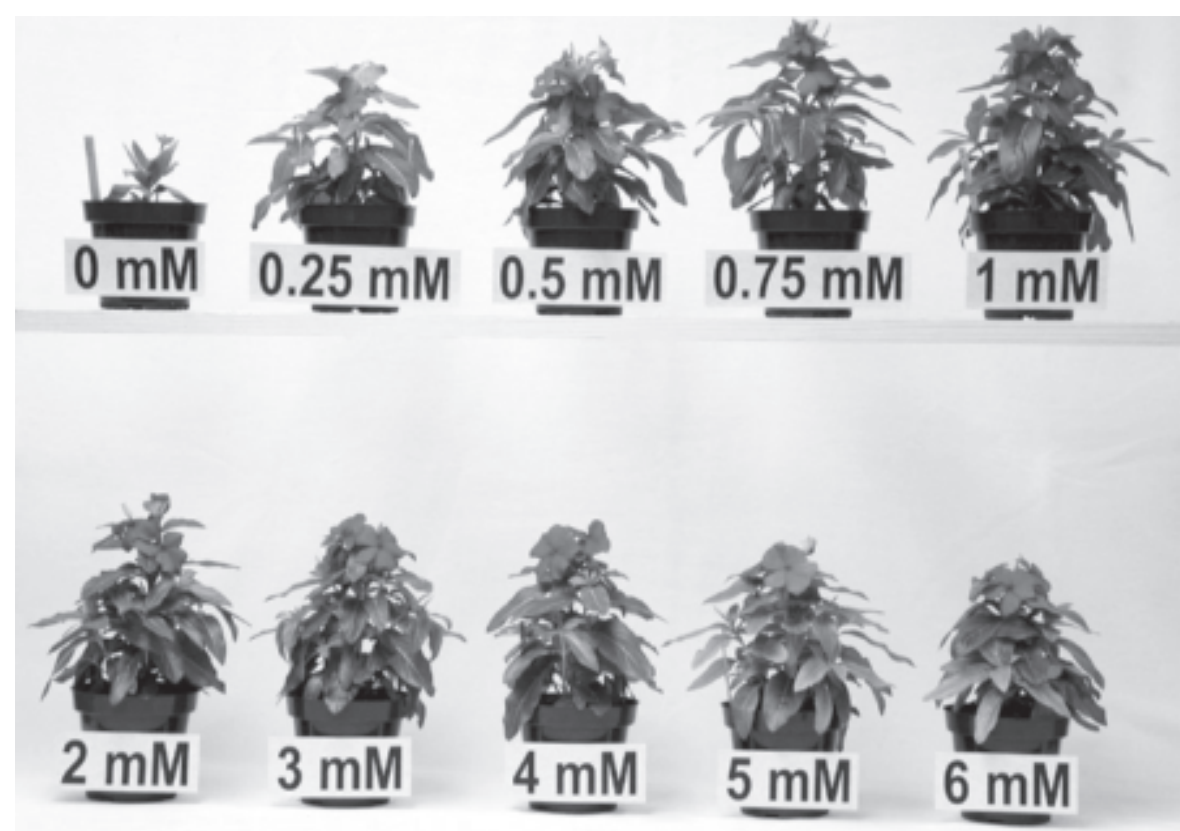

Fig. 3. Vinca 'Pacifica Red' grown at rates of 0 to $6 \mathrm{~mm} P$ in a recirculating subirrigation system (day 42, final harvest).

physiology and metabolism. Vegetative growth of the common bean in response to phosphorus nutrition. Crop Sci. 31:380-387.

Marconi, D.J. and P.V. Nelson. 1984. Leaching of applied phosphorus in container media. Scientia Hort. 22:275-285.

Nelson, P. 1996. Macronutrient fertilizer programs. In: D.W. Reed (ed.). Water, media and nutrition for greenhouse crops. Ball Publ., Batavia, Ill.

Nishimoto, R.K., R.L. Fox, and P.E. Parvin. 1975. External and internal phosphate requirements of field grown chrysanthemums. HortScience $10: 279-280$

Passarinho, J.A., M.L. Rodrigues, M.L. Osorio, C.P.P Ricardo, and M.M. Chaves. 2000. Physiological

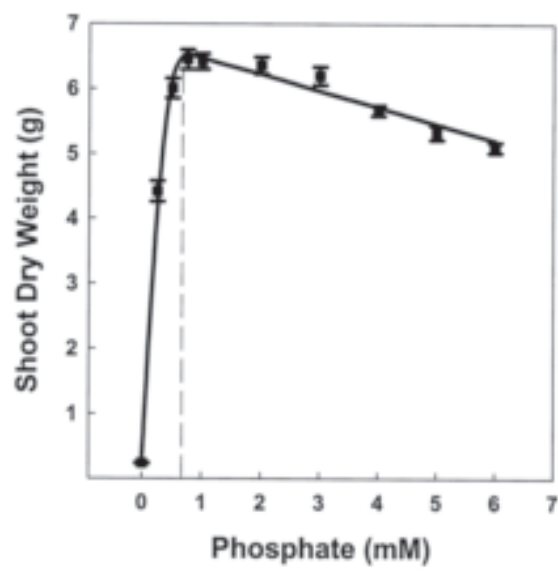

Fig. 4. Final harvest dry shoot weight (g) of vinca 'Pacifica Red' grown at rates of $0,0.25,0.5$, $0.75,1,2,3,4,5$, and $6 \mathrm{~mm} \mathrm{P}$ in a recirculating subirrigation system (day 42, final harvest). Dashed line indicates optimum mM P as defined by where the linear joins the quadratic line of the segmented quadratic-linear model. Bars indicate \pm standard error of the mean

\section{E-176.}

Williams, K.A. and P.V. Nelson. 1996. Modifying a soilless root medium with aluminum influences phosphorus retention and chrysanthemum growth. HortScience 31:381-384.

esponses of Lupinus mutabilis to phosphoru nutrition and season of growth. Journal of Plan Nutrition 23:487-505.

Reed, D.W. 1996. Closed production systems for containerized crops: Recirculating subirrigation and zero-leach systems, p. 221-245. In: D.W. Reed (ed.). Water, media and nutrition for greenhouse crops. Ball Publ., Batavia, Ill.

Soundy, P., D.J. Cantliffe, G.J. Hochmuth, and P.J. Stoffella. 2001. Nutrient requirements for lettuce transplants using a flotation irrigation system. I. Phosphorus. HortScience 36:1066-1070.

Warncke, D.D. and D.M. Krauskopf. 1983. Greenhouse growth media: Testing and nutrition guidelines. Mich. State Univ. Coop. Ext. Bul.
Yeager, T.H. and D.L. Ingram. 1986. Growth response of azaleas to fertilizer tablets, superphosphate, and dolomitic limestone. HortScience 21:101-103.

Yeager, T.H. and R.D. Wright. 1982. Pine bark-phosAnal. 13:57-66.

Yelanich, M.V. and J.A. Biernbaum. 1993. Rootmedium nutrient concentrations and growth of poinsettia at three fertilizer concentrations and four leaching fractions. J. Amer. Soc. Hort. Sci. 118:771-776. phorus relationships. Commun. In: Soil Sci. Plant 